\title{
Morphological characterization of remaining specimens of the Curraleiro horse in Central Brazil
}

\section{Caracterização morfológica de espécimes remanescentes do cavalo Curraleiro no Brasil Central}

\author{
Danilo Conrado Silva1*; Maria Clorinda Soares Fioravanti²; Paulo José Bastos \\ Queiroz ${ }^{3}$; Marcelo Corrêa da Silva4; Sarah Amado Ribeiro5; Sabrina Sara Moreira \\ Duarte ${ }^{6}$; Samara Socorro Silva Pereira6; Alex Silva da Cruz; Lysa Bernardes \\ Minasi7; Aparecido Divino da $\mathrm{Cruz}^{7}$
}

\section{Highlights}

Curraleiro horses are small, light, and have proportional linear measures. Intermediate capacity for speed and strength has been demonstrated. It supports weight on the back compatible with other Brazilian Creole equine breeds. Indices have categorized Curraleiro horses with saddling aptitude and fast work. This is the first morphological study of the remaining Curraleiro horse.

\begin{abstract}
This study aimed to carry out the morphological characterization of the remaining specimens of the Curraleiro horse in municipalities of the state of Goiás, Brazil. Forty male horses were evaluated using the age of five years as a criterion. Sixteen linear measurements and 13 zootechnical indices were obtained. Subsequently, the mean, standard deviation, minimum, maximum, and covariances of these measures and indices were obtained using the software IBM SPSS Statistics for Windows. The measures withers height (WH), croup height $(\mathrm{CH})$, midback height $(\mathrm{MH})$, sternum-to-ground height $(\mathrm{SH})$, chest index $(\mathrm{Cl})$, and estimated weight

1 Prof. Dr., Academic Institute of Agrarian Sciences and Sustainability, Universidade Estadual de Goiás, UEG, West Campus, São Luís de Montes Belos, GO, Brazil. E-mail: danilo.silva@ueg.br

2 Profa Dra, Animal Science Postgraduate Program, School of Veterinary Medicine and Zootechny, Universidade Federal de Goiás, UFG, Goiânia, GO, Brazil. E-mail: mariaclorinda@gmail.com

3 Prof. Dr., School of Veterinary Medicine and Zootechny, UFG, Goiânia, GO, Brazil. E-mail: paulo.queiroz@ufg.br

${ }^{4}$ Prof. Dr., Agribusiness Program, Universidade Federal da Grande Dourados, UFGD, Itahum, MS, Brazil. E-mail: marcelo-correadasilva@hotmail.com

${ }^{5}$ Doctoral student, Biotechnology and Biodiversity Postgraduate Program, UFG, Goiânia, GO, Brazil. E-mail: sarahamado@hotmail.com

${ }^{6}$ Postgraduate students, Genetics and Molecular Biology Postgraduate Program, UFG, Goiânia, GO, Brazil. E-mail: sabrina.sara.ssm@gmail.com; samarasocorrosilva@hotmail.com

7 Profs. Drs., Master Program in Genetics, School of Medical Science and Health, Pontifícia Universidade Católica de Goiás, PUC-Goiás, Goiânia, GO, Brazil. E-mail: a.silva.cruz@hotmail.com; minasi@pucgoias.edu.br; acruz@pucgoias. edu.br

* Author for correspondence
\end{abstract}

Received: Apr. 15, 2021 - Approved: Oct. 29, 2021 
(W) allowed characterizing Curraleiro horses as small-sized, light, and fast, with proportional measures. The dactyl-thoracic index (DTI), body index (BI), conformation index (CFI), load index 1 and 2 (LOI1 and LOI2), and compactness index 1 and 2 (COI1 and COI2) showed that the Curraleiro horse has an intermediate capacity for speed and strength, bearing considerable weight on the back, with saddling aptitude and fast work. These results represent the beginning of the formation of a database that may contribute to future studies and the conservation of the Curraleiro horse in the state of Goiás.

Key words: Zootechnical indices. Linear measures. Creole breeds. Local breeds. Animal genetic resource.

\section{Resumo}

O objetivo deste trabalho foi a realização da caracterização morfológica de espécimes remanescentes do cavalo Curraleiro em municípios do estado de Goiás, Brasil. Foram avaliados 40 cavalos machos, tendo como critério a idade a partir de cinco anos, dos quais se obteve 16 medidas lineares e 13 índices zootécnicos. Posteriormente, a média, o desvio padrão, o mínimo, o máximo e as covariâncias dessas medidas e índices foram obtidos por meio da utilização do software IBM SPSS Statistics for Windows. As medidas altura da cernelha (AC), altura da garupa (AG), altura do costado (ACost), vazio subesternal (VAZ), índice peitoral (IP) e peso estimado (P) permitiram caracterizar os cavalos Curraleiros como um grupo de pequeno porte, leve, veloz e com medidas proporcionais. Os índices dáctilo-torácico (IDT), corporal (IC), de conformação (ICF), de carga 1 e 2 (ICG1 e ICG2) e de compacidade 1 e 2 (ICO1 e ICO2) demonstraram que o cavalo Curraleiro tem capacidade intermediária para velocidade e força, suportam considerável peso sobre o dorso, e possuem aptidão para sela e tração ligeira. Tais resultados representam o início da formação de uma base de dados que pode contribuir para estudos futuros e a conservação do cavalo Curraleiro no estado de Goiás.

Palavras-chave: Índices zootécnicos. Medidas lineares. Raças crioulas. Raças locais. Recurso genético animal.

The European colonization of the American continent in the 16th century spread cattle raising, mainly from the Iberian Peninsula, in the new continent in a remarkable scenario of climate and cultural diversification. Horses were among the animals brought in by the settlers. The Brazilian horse underwent major morphophysiological changes as it expanded throughout the Brazilian territory under the most varied environmental conditions and was subjected to different selection pressures by man, giving rise to groups of animals with peculiar physical types (Lucena, Vianna, Berbari, Sales, \& Diniz, 2016; Velden, 2018).

Untilthe1950s, the Crioulo, Mangalarga, Campolina, and Comum equine breeds were established in Brazil, the latter made up of national horses of various types not belonging to the other breeds. Nordestino, Mimoseano, Bahia, Curraleiro Mato-Grossense, Curraleiro Goiano, and Guarapuavano were among the groups that made up the Common breed (Silva, Pedroso, Fioravanti, \& Silva, 2018).

Although evidence in the literature demonstrates the existence of a local horse belonging to the ancient Comum breed and adapted to the environmental and productive conditions of the state of Goiás (Silva et al., 2018), only in the past decade this group of equines became the object of characterization and research. Silva et al. (2019) analyzed the content of interviews with remaining 
breeders of this local horse found in the state of Goiás and concluded that there were specimens called Curraleiro horse, although rare. However, some individuals could be located, grouped according to common and specific characteristics, and differentiated from other equine breeds recognized in Brazil. Resistance to work and environmental conditions, small to medium size, and resistant hooves adapted to the soil of the region were the main characteristics that emerged from this first attempt to characterize the socalled Curraleiro horse (Silva et al., 2019), but morphometric measures have not yet been described for this group of animals.

Morphometric analyses allow to properly classify breeds or groups of animals through evaluations of linear and angular body measurements, which can predict their functionality, performance, and, consequently, the economic value (Gonçalves, Costa, Rezende, Rocha, \& Leite, 2012; Meira et al., 2013). In addition, the definition of equine morphometry enables to determine whether the animal is subjected to activities compatible with its physical structure, contributing to its well-being, less physical strain, and high ability to perform tasks efficiently (Rezende et al., 2014). This study aimed to carry out the morphological characterization of remaining Curraleiro horses in the state of Goiás, Brazil.

Visits to the municipalities of Cavalcante, Nova Roma, laciara, and Silvânia, located in the state of Goiás, Central Brazil, allowed the identification of local equines remaining from the ancient group of horses called Curraleiro. This identification was carried out through interviews, which allowed the characterization of the equines from interviews with breeders and experts of local horses. The interview content was previously published (Silva et al., 2019). Parallel to this identification, linear measurements of 40 male, adult, castrated Curraleiro horses, with an approximate age between five and 15 years, were obtained using a hypometer and a measuring tape. Animal measurements were conducted within the scope of field practical classes authorized by the Ethics Committee on the Use of Animals (CEUA-UFG) under registration numbers 150/2010 and 021/2016.

Sixteen linear measurements were obtained from the group of horses, as described by McManus et al. (2005), as follows: withers height $(\mathrm{WH})$, back height $(\mathrm{BaH})$, croup height $(\mathrm{CH})$, midback height $(\mathrm{MH})$, sternumto-ground height $(\mathrm{SH})$, head length $(\mathrm{HL})$, neck length (NL), back-loin length $(B L)$, shoulder bone length (SL), croup length (CL), body length (BL), head width (HW), chest width (CW), hip width (HiW), chest girth (ChG), and cannon girth (CaG).

Thirteen zootechnical indices were calculated from the linear measurements (McManus et al., 2005):

Withers height to croup height ratio $(\mathrm{WCR}=\mathrm{WH} / \mathrm{CH})$.

Chest index $(\mathrm{Cl}=\mathrm{MH} / \mathrm{SH})$.

Dactyl-thoracic index (DTI = CaG/ChG).

Estimated weight $(\mathrm{W}=\mathrm{ChG3} \times 80): \mathrm{W}$ $>550 \mathrm{~kg}=$ large or hypermetric horses, $350<$ $\mathrm{W}<550=$ medium or eumetric horses, and $\mathrm{P}<$ $350 \mathrm{~kg}=$ small or ellipometric horses.

Body index $(\mathrm{BI}=\mathrm{BL} / \mathrm{ChG}): \mathrm{BI}>0.90=$ long-sized horse (suitable for speed), $0.86<$ $\mathrm{BI}<0.88=$ medium-sized horse (intermediate aptitude between speed and strength), and $\mathrm{BI}<0.85=$ short-sized horse (suitable for strength). 
Thoracic index $(\mathrm{TI}=\mathrm{CW} / \mathrm{ChG}): \mathrm{TI}<$ $0.85=$ long-sized animal, $0.86<\mathrm{TI}<0.88=$ medium-sized animal, and $\mathrm{TI}>0.90=$ shortsized animal.

Conformation index $(\mathrm{CFI}=\mathrm{ChG} 2 / \mathrm{WH})$ : a riding horse has an ideal CFI of 2.1125 and values above that indicate animals suitable for work.

Load index $1\left(\right.$ LOI1 $\left.=\left(\mathrm{ChG}^{2} \times 56\right) / \mathrm{WH}\right)$ : this index indicates the weight, in kilograms, that the animal can support without excessive effort on its back, working at a trot or gallop.

Load index $2\left(\mathrm{LOI}_{2}=\left(\mathrm{ChG}^{2} \times 95\right) /\right.$ $\mathrm{WH}$ ): this index indicates the weight, in kilograms, that the animal can support without exaggerated effort on its back, working at a walking speed. WH).

Relative body index $(\mathrm{RBI}=(\mathrm{BL} \times 100) /$ $\mathrm{CH} / 2)$.

Degree of saddling $(\mathrm{DS}=\mathrm{BaH}-(\mathrm{WH}+$

Compactness index 1 (COI1 = (W/ WH)/100): equines suitable for heavy work should present values above 3.15, while values close to 2.75 indicate animals for light work and close to 2.60 indicate animals suitable for riding (saddling).

Compactness Index $2(\mathrm{COI} 2=[\mathrm{W} /(\mathrm{WH}$ - 1)]/100): this index also indicates the animal's aptitude. Values above 9.5 indicate animals for heavy work, between 8.0 and 9.5 indicate animals for light work, and between 6.0 and 7.75 indicate animals for riding (saddling).
Subsequently, the mean, standard deviation, minimum, maximum, and coefficients of variation of measures and indices were obtained using the statistical application SPSS ${ }^{\circledR}$ (IBM Corp. Released 2015. IBM SPSS Statistics for Windows, Version 23.0. Armonk, NY: IBM Corp).

Table 1 shows the mean values of the linear measurements and zootechnical indices obtained from the measurement of Curraleiro horse specimens found in the state of Goiás.

The evaluated Curraleiro horses had a mean withers height $(\mathrm{WH})$ of $1.33 \mathrm{~m}$, which characterizes them as small-sized horses (McManus et al., 2005). This characteristic corroborates with the historical records described by Silva et al. (2018). According to these authors, reports from 1908, 1913, and 1964 described the Curraleiro horse as a small and robust equine, which satisfactorily met the work needs of cattle breeders in the state of Goiás. More specifically, the report dated 1964 described these horses as small, with a maximum size that would reach the mean height of horses in Brazil at that time. A study on the characterization of Curraleiro horses by analyzing the content of interviews with breeders of these animals (Silva et al., 2019) showed that their small size was a marked characteristic and considered adequate by the breeders due to the local vegetation and landscape features. 
Table 1

Linear measurements and zootechnical indices obtained from the measurement of remaining specimens of the Curraleiro horse in Goiás $(n=40)$, Central Brazil

\begin{tabular}{|c|c|c|c|c|c|c|c|}
\hline & Characteristic & Acronym & Mean & SD & Minimum & Maximum & CV (\%) \\
\hline \multirow{5}{*}{ Height (m) } & Withers & WH & 1.33 & 0.12 & 1.12 & 1.85 & 9.02 \\
\hline & Back & $\mathrm{BaH}$ & 1.26 & 0.06 & 1.08 & 1.37 & 4.76 \\
\hline & Croup & $\mathrm{CH}$ & 1.32 & 0.07 & 1.13 & 1.45 & 5.30 \\
\hline & Midback & $\mathrm{MH}$ & 0.59 & 0.06 & 0.42 & 0.71 & 10.17 \\
\hline & Sternum-to-ground & $\mathrm{SH}$ & 0.70 & 0.06 & 0.49 & 0.77 & 8.57 \\
\hline \multirow{6}{*}{ Length (m) } & Head & HL & 0.55 & 0.10 & 0.41 & 0.84 & 18.18 \\
\hline & Neck & NL & 0.62 & 0.10 & 0.49 & 0.93 & 16.13 \\
\hline & Back-loin & $\mathrm{BL}$ & 0.76 & 0.09 & 0.60 & 1.10 & 11.84 \\
\hline & Shoulder bone & SL & 0.59 & 0.11 & 0.44 & 0.90 & 18.64 \\
\hline & Croup & CL & 0.47 & 0.09 & 0.38 & 0.78 & 19.15 \\
\hline & Body & $\mathrm{BL}$ & 1.33 & 0.08 & 1.14 & 1.49 & 6.01 \\
\hline \multirow{3}{*}{ Width (m) } & Head & HW & 0.23 & 0.09 & 0.17 & 0.52 & 39.13 \\
\hline & Chest & CW & 0.34 & 0.09 & 0.24 & 0.61 & 26.47 \\
\hline & Hip & HiW & 0.48 & 0.12 & 0.37 & 0.99 & 25.00 \\
\hline \multirow{2}{*}{ Girth (m) } & Chest & ChG & 1.56 & 0.11 & 1.37 & 1.99 & 7.05 \\
\hline & Cannon & $\mathrm{CaG}$ & 0.18 & 0.05 & 0.15 & 0.47 & 27.78 \\
\hline \multirow{13}{*}{ Index } & Withers to croup height ratio & WCR & 1.01 & 0.06 & 0.93 & 1.34 & 5.94 \\
\hline & Chest & $\mathrm{Cl}$ & 0.84 & 0.17 & 0.67 & 1.12 & 20.24 \\
\hline & Dactyl-thoracic & DTI & 0.12 & 0.04 & 0.09 & 0.31 & 33.33 \\
\hline & Estimated weight & W & 306.3 & 75.59 & 205.71 & 630.45 & 24.68 \\
\hline & Body & $\mathrm{BI}$ & 0.86 & 0.06 & 0.62 & 0.93 & 6.98 \\
\hline & Thoracic & $\mathrm{TI}$ & 0.21 & 0.05 & 0.15 & 0.39 & 23.81 \\
\hline & Conformation & CFI & 1.83 & 0.27 & 1.47 & 3.02 & 14.75 \\
\hline & Load 1 & LOI1 & 102.44 & 15.20 & 82.11 & 169.29 & 14.84 \\
\hline & Load 2 & LOI2 & 168.51 & 39.14 & 139.30 & 287.18 & 23.23 \\
\hline & Relative body & $\mathrm{RBI}$ & 100.06 & 5.98 & 78.17 & 110.32 & 5.98 \\
\hline & Degree of saddling & DS & -0.065 & 0.05 & -0.29 & -0.02 & 76.92 \\
\hline & Compactness 1 & COI1 & 2.30 & 0.54 & 1.61 & 4.81 & 23.48 \\
\hline & Compactness 2 & $\mathrm{COI} 2$ & 9.28 & 4.07 & 4.28 & 20.33 & 43.86 \\
\hline
\end{tabular}


Melo, Pires, Ribeiro, Santos and Silva (2011) conducted a zoometric study on the remaining Brazilian Nordestino equine breed and argued that the small size of Nordestino horses could be due to the high inbreeding between these animals, as well as extensive and poor management conditions, subjecting them to nutritional deficits. Similarly, Curraleiro horses were subjected to the same selection pressures, which may also explain their small size.

Head length $(\mathrm{HL})$ is one of the important variables that indicate the breed expression of animals (Gonçalves et al., 2012). Curraleiro horses from Goiás showed a mean HL of 0.55 $\mathrm{m}$, numerically equal to that observed for the Campeiro horse $(0.55 \mathrm{~m})$ (McManus et al., 2005) and close to the values described for Pantaneiro (0.54 m) (Miserani et al., 2002), Nordestino (0.53 m) (Melo et al., 2011), and Baixadeiro horses (0.49 m) (Chung, 2019).

Overall, the linear measurements found in the remaining Curraleiro horses are numerically close to those observed in other Brazilian equine breeds, for which natural selection was also very important in their evolutionary processes, such as the Nordestino (Melo et al., 2011), Campeiro (McManus et al., 2005), Baixadeiro (Chung, 2019), and Pantaneiro (Miserani et al., 2002). The mean linear measurements described for the Mangalarga Marchador breed (Santiago et al., 2013, 2014) are numerically higher demonstrating the difference in morphometric characteristics when genetic selection is performed by humans compared to that performed naturally.

The similarity of withers height $(\mathrm{WH})$ and croup height $(\mathrm{CH})$ values is desirable for the horse balance (Melo et al., 2011). In the present study, the mean $\mathrm{CH}$ was $1 \mathrm{~cm}$ lower than the mean $\mathrm{WH}$. Furthermore, the $\mathrm{WH}$ to $\mathrm{CH}$ ratio $(\mathrm{WCR}=\mathrm{WH} / \mathrm{CH})$ was 1.01 . Values close to the unit indicate a balance between $\mathrm{WH}$ and $\mathrm{CH}$ (Chung, 2019). The occurrence of important differences between $\mathrm{WH}$ and $\mathrm{CH}$ can be caused by the abnormal opening of the joint angles of the thoracic and pelvic limbs for more or less, impairing walking and strength (McManus et al., 2005).

The lower midback height $(\mathrm{MH})$ and higher sternum-to-ground height (SH), both variables used to calculate the chest index $(\mathrm{Cl}$ $=0.84$ ), showed that the remaining Curraleiro horses can be considered "far from the ground," which is a consequence of relatively long limbs, favoring speed. Otherwise, the animals would be considered "close to the ground" if $\mathrm{MH}$ were higher than $\mathrm{SH}$ and more suitable for work (McManus et al., 2005).

The estimated weight (W) of $306.3 \mathrm{~kg}$ for Curraleiro horses corresponds to the weight of small or ellipometric horses (McManus et al., 2005), and confirms the small size described by breeders in a previous study (Silva et al., 2019). Although the Curraleiro horse is small and light, its mean dactyl-thoracic index (DTI = 0.12 ) indicates a hypermetric animal, short, or heavy horse (Rezende, Souza, Mota, Oliveira, \& Jardim, 2016). Italso favors the use of Curraleiro horses for work activities (Melo et al., 2011; Pimentel et al., 2014). Similar to Curraleiro, the Nordestino horse was considered suitable for heavy work despite being light and small due to a DTI value of 0.115 (Melo et al., 2011).

The body index $(\mathrm{BI}=0.86)$ classified the Curraleiro horse as a medium-sized horse (Rezende et al., 2016), that is, it has an intermediate aptitude between speed and strength, similar to the Campeiro (McManus et 
al., 2005) and Nordestino horses (Melo et al., 2011). The mean conformation index (CFI) of 1.83 indicates an aptitude for riding (saddling) activities (Rezende et al., 2016).

The load indices 1 (LOI1) and 2 (LOI2) indicated that the remaining Curraleiro horses can support $102.44 \mathrm{~kg}$ at a trot or gallop and $168.51 \mathrm{~kg}$ at a walking speed on their back without excessive effort, respectively. Comparatively and considering LOI 1 and LOI2, the Curraleiro horse supports, on average, more weight on its back than the Nordestino horse (Melo et al., 2011) and less weight than the Campeiro horse (McManus et al., 2005).

The degree of saddling (DS) was -0.065 , a value close to that observed for the Campeiro horse and considered within the ideal range, in which there is less risk of injury due to incorrect positioning of the saddle on the animals' back (McManus et al., 2005). The results obtained for the compactness indices showed that the Curraleiro horse can be considered suitable for riding $(\mathrm{COI} 1=2.30)$ and work $(\mathrm{COI} 2=9.28)$, confirming that these animals can present more than one aptitude.

The morphological and functional characteristics described in this study for the remaining Curraleiro horses corroborate with historical records (Silva et al., 2018) and, more recently, the analysis content of interviews with breeders and experts on these animals (Silva et al., 2019). In the last case, interviewees described that the reduced body size and weight of Curraleiro horses are characteristics suitable for the work and handling of cattle in the Cerrado regions with low trees and stony soil located in the north and northeast of the state of Goiás. The study that characterized the Curraleiro horse through interviews also highlighted its rusticity, describing animals possibly more resistant to disease and with small and resistant hooves, similar to donkeys. Moreover, the present study showed intermediate attributes and riding aptitude, speed, and fast work in Curraleiro horses, demonstrating their versatility and importance of conservation for communities where they are found.

The remaining Curraleiro horses can be classified as a group of equines that present proportionality between their linear measurements. They are small and light animals, but specific indices showed that these equines have multiple and intermediate aptitudes for riding, speed, and fast work, also supporting weight on the back compatible with some Brazilian creole equine breeds. We emphasize the importance of developing other studies aimed at improving the morphogenetic knowledge of the potential equine genetic resource evaluated in this study, providing subsidies for the composition and implementation of projects aimed at the conservation of these animals

\section{Acknowledgments}

The authors offer special thanks to the breeders of the studied horses and the staff from the Federal University of Goiás directly involved in this study. We would also like to thank the Coordination for the Improvement of Higher Education Personnel (CAPES) for granting the graduate scholarships that allowed this study to be carried out. 


\section{References}

Chung, L. B. O. (2019). Caracterização morfológica, índices morfométricos e avaliação testicular do cavalo baixadeiro. São Luís, MA: Editora Valle Indústria Gráfica e Comércio LTDA.

Gonçalves, R. W., Costa, M. D., Rezende, A. S. C., Rocha, V. R., Jr., \& Leite, J. R. A. (2012). Efeito da endogamia sobre características morfométricas em cavalos da raça Mangalarga Marchador. Arquivo Brasileiro de Medicina Veterinária e Zootecnia, 64(2), 419-426. doi: 10.1590/S0102-09 352012000200023

Lucena, J. E. C., Vianna, S. A. B., Berbari, F., Neto, Sales, R. L. M., Fo., \& Diniz, W. J. S. (2016). Caracterização morfométrica de fêmeas, garanhões e castrados da raça Campolina baseada em índices. Arquivo Brasileiro de Medicina Veterinária e Zootecnia, 68(2), 431-438. doi: 10.1590/1678-4162-8016

McManus, C., Falcão, R. A., Spritze, A., Costa, D., Louvandini, H., Dias, L. T.,... Garcia, J. A. S. (2005). Caracterização morfológica de equinos da raça campeiro. Revista Brasileira de Zootecnia, 34(5), 15531562. doi: $10.1590 / S 1516-3598200500$ 0500015

Meira, C. T., Pereira, I. G., Farah, M. M., Pires, A. V., Garcia, D. A., \& Cruz, V. A. R. (2013). Seleção de características morfofuncionais de cavalos da raça Mangalarga Marchador por meio da análise de componentes principais. Arquivo Brasileiro de Medicina Veterinária e Zootecnia, 65(6), 1843-1848. doi: 10.1590/S010209352013000600036

Melo, J. B., Pires, D. F., Ribeiro, M. N., Santos, D. O., \& Silva, H. G. O. (2011). Estudo zoométrico de remanescentes da raça equina Nordestina no Município de Floresta, Pernambuco - Brasil. Actas
Iberoamericanas de Conservación Animal, 1, 71-74. Recuperado de http://www. uco.es/conbiand/aica/templatemo_110_ lin_photo/articulos/2011/Melo2011 _1_71_74.pdf

Miserani, M. G., McManus, C., Santos, S. A., Silva, J. A., Mariantes, A. S., \& Abreu, U. G. P. (2002). Avaliação dos fatores que influem nas medidas lineares do cavalo pantaneiro. Revista Brasileira de Zootecnia, 31(1), 335-341. doi: 10.1590/ S1516-35982002000200007

Pimentel, M. L., Pinheiro, M., Maia, H., Fo., Sakamoto, S. M., Nobre, F. V., \& Dias, R. V. C. (2014). Parâmetros biométricos de Asininos (Equus asinus) utilizados em provas de corrida no estado do Rio Grande do Norte. Acta Veterinaria Brasilica, 8(2), 136-143. doi: 10.21708/ avb.2014.8.2.3579

Rezende, M. P. G., Souza, J. C., Mota, M. F., Oliveira, N. M., \& Jardim, R. J. D. (2016). Conformation index of horses of different genetic groups. Ciência Animal Brasileira, 17(3), 316-326. doi: 10.1590/1089-68 91v17i321194

Rezende, M. P. G., Souza, J. C., Mota, M. F., Jardim, R. J. D., Ramires, G. G., Silva, R. M., \& Souza, C. F. (2014). Morfometria corporal de equinos utilizados em trabalho, esporte e lazer em três municípios do Mato Grosso do Sul. Veterinária e Zootecnia, 21(4), 569-583. Recuperado de https:// www.researchgate.net/profile/MarcosRezende/publication/284178649

Santiago, J. M., Rezende, A. S. C., Fonseca, M. G., Abrantes, R. G. P., Lage, J., \& Lana, A. M. Q. (2013). Comparação entre as medidas morfométricas do rebanho atual de machos Mangalarga Marchador e dos campeões da raça. Boletim de Indústria Animal, 70(1), 46-52. doi: 10.17523/bia. v70n1p46 
Santiago, J. M., Rezende, A. S. C., Lana, A. M. Q., Fonseca, M. G., Abrantes, R. G. P., Lage, J.,... Resende, T. M. (2014). Comparação entre as medidas morfométricas de equinos Mangalarga Marchador de marcha batida e marcha picada. Arquivo Brasileiro de Medicina Veterinária e Zootecnia, 66(2), 635-639. doi: 10.1590/1678-41626870

Silva, D. C., Pedroso, A. C. B. R., Fioravanti, M. C. S., \& Silva, L. A. F. da. (2018). A história da formação das raças equinas no Brasil. Goiânia, GO: Espaço Acadêmico.
Silva, D. C., Silva, M. C., Goulart, F. F., Cruz, A. S. da, Moura, M. I., Fioravanti, M. C. S.,... Cruz, A. D. da. (2019). Identification of a historic horse ecotype analyzing speech content in central Brazil. Arquivo Brasileiro de Medicina Veterinária e Zootecnia, 71(3), 1047-1057. doi: 10.1590/1678-4162-10 269

Velden, F. F. V. (2018). Animais exóticos de origem europeia ou africana entre povos indígenas nas terras baixas da América do Sul: notas para pesquisas futuras. Estudios Latinoamericanos, 38, 141-172. doi: 10.36447/Estudios2018.v38.art8 
